Class Politics, Competitiveness and the Developmental State

\title{
Paul Cammack
}

Manchester Metropolitan University 


\section{Class Politics, Competitiveness, and the Developmental State}

The broad picture that Vivek Chibber's Locked in Place: State-Building and Late Industrialization in India (Chibber, 2003) paints of the trajectory of the developmental state in India is persuasive. Any will to install a regime able to discipline capital and transform the structure of production flared briefly and quickly died, and after independence domestic capitalists, never committed to an industrial planning regime with teeth, called the shots in an import-substituting regime in which they enjoyed rich pickings but suffered few constraints. As the core planning agency lacked the ability to command other areas of government, ministries disregarded plan objectives and issued licences indiscriminately, rendering the whole planning regime incoherent. Once embedded, moreover, the system developed its own momentum, and efforts to reform it failed. Chibber's account is far from conclusive - although he introduces valuable archival material, he tells us virtually nothing about the initial structure and subsequent evolution of production, finance and trade, and he offers the briefest of sketches of the 'Indian political class' and the 'Indian capitalist class'. Even so, I can readily accept that India's post-independence industrial planning and policy regime was ineffective, and institutionally embedded in a way that made it resistant to reform; and that India's capitalists rather liked it that way.

However, his critique of India's planners and capitalists is far from radical, and more neoliberal than Marxist in inspiration. Its focus on class revolves around the capacity of the state to build the kind of alliance with business that will secure capitalist development, rather than with the political economy of production and exploitation. And, I shall argue, his endorsement of a conventional neoclassical understanding of capitalist competition, coupled with his downbeat appraisal of the potential for the 'developmental state' today, brings him exactly into line with the postWashington Consensus World Bank. In all of this, it is his adoption of the Korean developmental state as a point of reference, and his interpretation of it, that sets the terms of the analysis.

\section{Embracing Korea}

Chibber fails to grasp the logic or the dynamics of the Korean developmental state. First, he is entirely uncritical - Korea is presented 
without qualification as the success story that contrasts with India's failure. Second, he takes no account of Korea's repressive labour regime, thereby making it impossible to understand the 'capitalist developmental state' or the alliance between the state and business. Third, his own explanation for the installation of the developmental state is perverse and unconvincing.

\section{An 'exemplar' developmental state}

Chibber describes Korea unequivocally at the outset as 'perhaps the exemplar developmental state in the postwar period': whereas in India 'the state's efforts to promote a dynamic industrial sector fell prey to the twin evils of bureaucratic paralysis and capitalist rent-seeking, Korean efforts were rewarded by unprecedented success' [4]. There is no hint here that the Korean state itself fell prey to 'bureaucratic paralysis' or 'capitalist rentseeking' in due course: indeed, the closing section of the introduction raises the issue of the reproduction of the developmental state exclusively with reference to the failure of reform in India in the 1960s. ${ }^{1}$ As a result, a fundamental imbalance is built into the analytical framework of the study.

Following Amsden and others, Chibber attributes the 'enormous success of Korea in making its traversal to a dynamic and efficient industrial economy' [5] to 'highly interventionist industrial planning':

The Korean and Taiwanese states had actively manipulated trade and exchange rates, the allocation of finance, as well as the price structure of the domestic economy; . . both countries not only had developed a large public enterprise sector but had also been active in directing the structure of private investment [6].

While cultural, institutional, economic, geographical and other factors played their part, he argues, the state made a significant contribution by virtue of its capacity, a combination of 'cohesiveness as a strategic actor' and the ability to 'extract performance from private firms' [7]. The Korean state, in sum, had 'the appropriate institutional backbone' [8] to install a developmental regime. Chibber adds to this standard account 'a new interpretation of the relevant period in Korean history': first, it succeeded in striking 'an alliance of sorts' with its domestic business class' [9]. Second, there was a 'deeper, structural factor' that explained the contrast:

Chang (1998), a source Chibber cites approvingly, gives ample evidence of the vicissitudes of the Korean developmental state from the 1980s onwards. See also Chang, Park and Yoo (2001) and Pirie (2005). 
In India the state opted for import-substituting industrialization (ISI), whereas in Korea greater emphasis was placed on export-led industrialization (ELI). I suggest that the two models generated different political incentive structures for the capitalist classes: ISI made it possible, and even rational, for Indian capitalists to resist the effort to build a state that could impose discipline in private firms; ELI, on the other hand, made it rational for Korean business to acquiesce to its own disciplining by a developmental state [10].

These two points provide the first two of four 'theses' set out in Chapter Two $[29,32]$. The third adds that 'Korea was able to switch from ISI to ELI because certain conditions virtually unique in the world economy were available to Korea, conditions that simply were not available to other LDCs' [39]. These arose from the fact that 'Japanese firms were vacating markets in the United States and bequeathing them to Korean firms, along with their marketing and sales outlets' [42]. This, then, is Chibber's Korea: a developmental state which enjoys success because it forms an alliance with a domestic capitalist class willing to accept disciplinary planning as a step towards export-led industrialization made possible by the ceding of US markets and associated marketing and sales outlets by Japanese firms.

\section{The absence of the working class}

It has never occurred to anyone before, least of all anyone attempting a class analysis of the developmental state, to ignore the labour regime inaugurated under Japanese rule and perfected under Park. Yet Chibber glosses entirely over this central feature of the Korean developmental state - the repressive regime instituted after 1961 through which labour was politically excluded, policed by the intelligence services, faced with intimidation and physical repression, and subjected to unparalleled levels of exploitation in the workplace. The squeezing of a new proletariat out of the countryside, the corralling of mostly female workers in dormitories alongside sites of production, the regime of exceptionally long working days and limited holidays and the enormous differentials between male and female wages are massively documented, yet play no part in his analysis. ${ }^{2}$

2 Among sources Chibber himself uses, see Amsden, 1990, pp. 13-14; among those he does not, see Deyo, 1987, passim. Deyo (p. 191) states the obvious: 'Labor discipline has been an important prerequisite for a development strategy that centers on manufacturing for world markets'. Neglect of this factor contributes to Chibber's refusal to accept the relevance of the Japanese colonial legacy. As Cumings remarks: 'In the postwar period Japan was shorn of a few features of its 1930s political economy. But in Taiwan and, later, in 
This removes at a stroke the most powerful explanation for the alliance between the developmental state and a fledgling domestic bourgeoisie weakly placed to exert hegemony for itself. One should not have to point out that the East Asian developmental state was pre-eminently a capitalist developmental state, and a central part of that was its creation and disciplining of an exploitable proletariat.

Once the class strategy of the developmental state is split down the middle, and one half is discarded, it is inevitable that 'the secret' of the alliance between the state and the domestic bourgeoisie will prove elusive. Eloquent testimony to this is provided by the glaring contradiction embedded in the last of the four theses which shape the study:

A full explanation for why the Indian National Congress was unsuccessful in installing a developmental state is that, in addition to facing a mobilized business class set against the project, Party leaders also demobilized a massive and quite organized labour movement thus reducing the state's leverage against the capitalist class [43].

As it happens, this argument is entirely unconvincing. In Argentina, Brazil, Mexico, and France alike, governments favouring capitalist development sought to break the back of autonomous labour movements and create new federations controlled by the state and willing to sign up to its project. The implication that the continuation of a powerful and independent labour movement in India not subordinated to a state developmental project would have helped to win the business class over is absurd. The glaring contradiction here, though, is that Chibber does not apply the same thesis to the Korean case. Unable to resort to the argument that the installation of the developmental state required an alliance between the state and labour, he suggests instead that it was the alliance with business that gave the Korean state the autonomy to carry its project forward: 'it was the success in striking an alliance of sorts with its domestic business class [emphasis mine] that gave the Korean political elite the space to build appropriate

South Korea the 1930 s model reappeared, in nearly all its aspects, including militarization and harsh repression of labor' (1987, pp. 58-59). Indeed, labour repression is the only social legacy of Japanese colonialism to which Haggard, Kang and Moon (1997, p. 868) will admit. If there was ever a case of consensus, this is it. Curiously, in one of the rare instances where Marx is cited, it is in connection with the 'bloody legislation against the expropriated' that attended the process of primitive accumulation, or the creation of fully commodified labour markets [14]. But Chibber never relates the thought to the Korean case. 
institutions'; although not sufficient in itself, 'the antecedent autonomy garnered by the alliance with business was necessary for the state-level processes to be effective' [9-10]. In this regard, then, Chibber's analytical framework is entirely incoherent. ${ }^{3}$

\section{Chibber's 'new interpretation'}

While dismissing neoliberal accounts of Korea's success, Chibber takes strenuous issue with 'statist' versions too, on the grounds that most of the literature 'has assumed that the project of state building was successful because the state was simply dominant over its industrial class' [31; see also 51-52]. He places particular weight on two sources from 1980: Jones and Sakong, who claim that 'the dominant partner is unequivocally the government', and that 'the government's wishes are tantamount to commands, and business dare not take them lightly'; and Mason et al., whose view is that 'it is the government that is the Chairman of the Board, with business holding a few of the directorships'. Chang is subsequently taken to task for suggesting, 'in his otherwise excellent article on Korean industrial policy', that 'the business community were like "criminals on parole on condition that they 'serve the nation through enterprise' and, economically, a paper tiger with little power to make investment decisions the ultimate capitalist prerogative"'.4 A couple more sources are mentioned, and on this basis Chibber finds a 'developing consensus' that the state was dominant over the capitalist class. This limited recourse to direct citation is supported by scattered references to the state's supposed 'unquestioned power over capitalists', or 'inordinate power over capitalists' [53], and by some strong formulations of Chibber's own:

3 There is another aspect to Chibber's identification of Korea as the 'exemplar developmental state' that distorts his analysis. He argues in relation to India's failure to introduce an effective developmental state that if a charge of teleology is to be avoided, 'it must be shown that the institutions in question which were not, in the end, installed - were in fact, on the political agenda at some critical juncture'; then goes on to say that 'The years immediately following Independence, 1947 to 1951, constituted just this kind of critical juncture, in which a strong developmental state was very much on the political agenda' [8-9]. But it was the Soviet Union that was the 'exemplar developmental state' of the time - and Chibber's failure to mention this gives a surreal quality to the discussion. He assumes far too lightly that the commitment of the Indian political class was unambiguously towards capitalist development, and recognised as such by the 'business class'.

4 The references to Jones and Sakong (1980, p. 67) and Mason et al. (1980, p. 263) appear at p. 54; Chang (1993, p. 152) is cited on p. 61. 
The developing consensus is thus statist in substance: industrial policy was successful because of the unique power the state had to override the proclivities of its own capitalist class, and it was this power that set Korea apart from other developing states [52].

Where I part company . . . is on the matter of whether the reforms in question were capable of securing a general dominance of the state over the business community, so that the state could impose its own agenda on the class, regardless of the latter's own perception of its interests [58].

It is one thing to say that the state initiates a new set of policies for future growth; it is quite another to insist that it can successfully impose them on its business class, regardless of the latter's preferences [62].

What are we to make of this? First, Chibber is guilty of a slippery use of language. He does not discriminate consistently between a 'weak' statist argument that the state was the senior partner and business the junior, and the 'strong' version in which the state simply imposes its preferences. This allows him ample opportunity, frequently taken, to affect to differ where in fact he agrees. And he is happy enough to declare that 'the state had an uncommon capacity to exert influence over its business class' [51], and even to use formulations which suggest that he even thinks the 'strong' thesis is sometimes applicable: on the early arrest and release of leading businessmen, for example, he comments: 'At one stroke, Park thus demonstrated that the junta held no brief against private property, while at the same time maintaining its dominance over the propertied class' [61].

Second, a number of leading scholars are not identified with this 'developing consensus'. Neither Cumings nor Johnson are, and he confesses himself unable to fathom the views of either Amsden or Wade - either when an earlier version of this chapter appeared in Politics \& Society in 1999, or in the current text. ${ }^{5}$ This seems to be a consensus that excludes the leading authorities on the topic.

Third, he does not at any point challenge (or for the most part even address) the evidence adduced by supposed proponents of the 'statist' thesis. Instead, he contents himself with generalities. This is well illustrated in relation to the argument singled out as 'the main theoretical pillar on which the claim of dominance rests' - the state's control of finance [58].

See Chibber (1999), p. 339, note 9; and the (virtually) identical note here at p. 267. 
Chibber's opening statement here is categorical:

There is no reason to think that the control of banks gives the state sufficient power to unilaterally set the agenda, in the form of a particular accumulation model. Capitalists have a countervailing power of their own, through their control over final investment. Statists provide no argument as to how the state can be immune to this power, even if it does enjoy financial hegemony [58].

On this basis, he proposes a reformulation: the state cannot coercively impose new conditions onto the entire class, but control of finance may give it 'an effective stick to wield against particular firms within the class' [58]. All well and good. But his point of reference appears to be some generic capitalist state with a fully constituted capitalist class with its own resources to invest [see in particular 63-64]. In contrast, the whole point of Chang's reference to the power to make investment decisions as the 'ultimate capitalist prerogative' was to highlight the exceptional character of the Korean regime, and it is this that needs to explored, to be either confirmed or rebutted. After all, the particular weakness of the domestic capitalist class in Korea is a constant point of reference in the literature, and Chibber accepts one of its most extreme formulations - the critique of Kohli by Haggard, Kang and Moon which argues that virtually nothing remained of Korea's industrial base by the mid-1950s. In their view, it was variously lost because of the division of Korea (in the case of most heavy industry), or in ruins by the time the Japanese departed ('The most important point to make about Japan's efforts at industrializing Korea . . is that they did not survive'), or destroyed in the Korean War. And they single out as the leading actors in its renaissance the chaebol created in the ISI period and lavishly supported by Syngmann Rhee - precisely those particular firms that were disciplined by Park. ${ }^{6}$ One could explore the empirical evidence further. Instead, I invite Chibber to tell us more about those elements of the Korean capitalist class in the 1960s, outside the particular firms who were disciplined, that had their own resources to invest in the period, and did so (or refused to do so) either in defiance of the state or without its support. Where, in other words, are the 'large swathes of the entire class' [52] beyond these 'particular firms within the class'? Where is the

6 See Haggard, Kang and Moon (1997), especially pp. 872 and 875-6. They cite data from Kim (1997) in support of their argument, while Chibber, in contrast, quotes Kim out of context as evidence of the 'statist consensus' and ignores his data. 
'countervailing power of capital' when the state is the direct source of the capital, or the sole gateway to it? On the evidence, it emerged in Korea only from the late 1980s onwards as government controls began to fall away. ${ }^{7}$ And Chibber himself remarks, at a different point in the text, that 'at least in manufacturing, the Chaebols were the economy' [169]. If so, the distinction he makes is meaningless for the Korean case.

Fourth, the singling out of finance in any case caricatures the 'statist' case. While the importance of state control of finance has rightly been widely noted, it is one of many massively documented factors underlying the unusual leverage the Korean developmental state held over the 'capitalist class', many of which Chibber himself describes. Yet Chibber, caught in the trap of arguing from the general to the particular, ends by denying the exceptional character of the Korean state altogether:

This is not to deny that the state wielded considerable power over domestic business; but all capitalist states have such power to varying degrees. The statists do not present any compelling reason to believe that such power was qualitatively greater in Korea than elsewhere [52].

Apart from the fact that the state provided 57.9 per cent of finance capital between 1962 and 1985, that is; and that Korean firms were the most highly leveraged in the world; and that tight restrictions kept foreign direct investment very low, and controlled by the state; ${ }^{8}$ and that the Foreign Exchange Concentration System and the Foreign Exchange Management Act between them denied capitalists the right to dispose freely of their export earnings; and that domestic consumption was severely repressed, which denied capitalists easy opportunities to make profits in the home market; and that mergers or reallocation of production lines were imposed by the state in order to avoid 'excessive competition', as were entry restrictions and regulations on capacity expansion, enforceable by fines and prison sentences, and liquidations, nationalizations and sales to remove inefficient

7 Chang, Park and Yoo (2001) describe in some detail how Korea lost its ability to dictate patterns of investment from this point in time. This spelt the unravelling of the exceptional character of the regime. Pirie (2005) brings the story up to date.

8 Chang, 1993. Chang also draws attention to the Park regime's emulation of Japanese corporatism, its obsession with capital accumulation, and the value it attached to heavy and chemical industries. 
producers. ${ }^{9}$ Apart from, that is, the creation of a state-orchestrated domestic economy oriented by a Schumpeterian rather than a neo-classical view of competition, in which the chaebol were dependent on state-created rents and driven to compete against each other for recognition by the state. As if this were not enough, Chibber himself mentions a host of other factors, all familiar from the literature: the nationalization of the banks [52, 60]; the authority of the Economic Planning Board [52]; the 'thoroughly clientelistic' nature of the state's relation to Korean business under Syngmann Rhee [56]; the initial imprisonment of the biggest industrialists [57, 60-61]; Park's selective removal of corrupt bureaucrats, pursued 'not to eliminate corruption but to confine it strategically so that it would serve the political ends of the regime, without interfering with its economic strategy' [59]; Park's 'political will' [64] - a factor not as easily separated as Chibber assumes from 'some unique capacity of the Korean state'; the regime's alliance with farmers and small business, the former made possible by the earlier land reform but cemented by the forgiveness of rural debt [68]; Park's further tightening of his grip on power in 1963-4, through the reshaping of the planning regime and the holding of elections [69-70]; the lucrative contracts controlled by the state as a consequence of US aid spending and military procurement, the latter particularly in relation to the Vietnam War [70]; the effectiveness of the regime's monitoring of exports and its punishment of failure [71 and ft. 53, p. 271]; the use of the Korean Traders Association and similar sectoral associations as compulsory, statecontrolled disciplinary devices [156, 168-9], and the fact that the contact between Korean and Japanese 'business' on which such weight is placed was actually channelled through Park and his former military instructor, Yukawa - a detail that implausibly appears without comment in a passage aimed to demonstrate that the strategy was 'pushed by business itself' [7475, 82]. There are perhaps the rudiments here, after all, of a case for Korean exceptionalism.

Fifth, Chibber turns out anyway to grossly misrepresent the supposed 'statism' of his principal sources. To make the point briefly, we need only consider the following, quoted by Johnson from Mason et al:

9 'What is notable in the conduct of such 'reorganisation' programmes is that even the economically and politically powerful conglomerates, chaebols, as individual conglomerates, were not immune to state discipline, although, as a group, they were certainly privileged in their access to various rents' (Chang, 1993, p. 149). 
The rapid economic growth that began in the early 1960s and has accelerated since then has been a government-directed development in which the principal engine has been private enterprise. The relationship between a government committed to a central direction of economic development and a highly dynamic private sector that confronts the planning machinery with a continually changing structure of economic activities presents a set of interconnections difficult to penetrate and describe. Planning in South Korea, if it is interpreted to include not only policy formulation but also the techniques of policy implementation, is substantially more than "indicative." The hand of government reaches down rather far into the activities of individual firms with its manipulation of incentives and disincentives. At the same time, the situation can in no sense be described in terms of a command economy. ${ }^{10}$

Far from claiming that the state could impose its own agenda on the class regardless of its preferences, Mason et al. appear to categorically deny it.

Sixth and last, Chibber's manoeuvre has been anticipated. Chalmers Johnson again:

Ever since the catchphrase "Japan, Inc" was invented to refer to the Japanese government-business relationship, writers on the subject have found it de rigueur to misinterpret it to mean Japanese government domination of the economy and then to demolish it. But Taira's enigma, with regard to Japan or the role of government in Korea and Taiwan, does not imply domination; it refers explicitly to the coexistence of authoritarianism and capitalism - and that must be explained. ${ }^{11}$

Precisely so. Chibber is so caught up with an imaginary dispute over 'state domination' that he forgets that the Korean developmental state was an authoritarian capitalist project through and through. In missing this, as we have seen, he misses both the link to Japanese colonial rule (to which Park himself was a living monument), and the roots of the repressive labour regime. This is of a piece with his refusal to believe that control of finance by the state (and the many other mechanisms identified in the literature) could give it a hold over the capitalist class. It betokens a comprehensive failure to grasp the logic of the Korean model of development, or in other

10 Mason et al. (1980), p. 254, cited in Johnson (1987), p. 141. Compare Park himself: 'The economic planning or long-range development program must not be allowed to stifle creativity or spontaneity of private enterprise' (quoted in Amsden, 1989, p. 50).

11 Johnson (1987), p. 140. [Koji] Taira's enigma (quoted ibid., p. 137) is as follows: 'The combination of an absolutist state with a capitalist economy from 1889 to 1947 has been an enigma, far from fully unravelled, among scholars interested in Japanese economic history'. 
words the political economy of the Korean capitalist developmental state. The same is true, of course, of his clinching argument - the issue of access to US markets for light manufactured goods as an explanation for the successful installation of an export-led regime. Chang provides the response here, in an excellent point Chibber was ill-advised to ignore:

The Korean success was based on a conception of economic development which encompassed far more than mere trade strategy. Development strategy is a multidimensional problem involving such wide-ranging areas as the establishment of long-term targets for growth and structural change, investment in productive facilities and infrastructure, the supply of an adequate labour force with industrial competence and discipline, and technological catching-up and development. Development strategy should no longer be discussed in terms of the misconceived dichotomy between export-led (or outwardlooking) and import-substituting (or inward-looking) strategies. ${ }^{12}$

In Korea after 1961, import-substituting and export-oriented activities alike were characterized by 'the pursuit of long-term dynamic efficiency through the state's constant creation of rents'. ${ }^{13}$ It makes no sense to contrast 'inefficient' import substitution with 'efficient' export promotion. Light manufactures played their part. But the principal focus of the disciplinary developmental state was on massive exercises in import substitution which would only pay off in terms of new exports from heavy industry in the 1970s. Import substitution as much as export promotion was fundamentally characterized by the search for productivity and competitive advantage, as indeed was production in state-owned enterprises. This, after all, is what Asia's Next Giant was all about. ${ }^{14}$ By ignoring all this, then conflating planning, the disciplinary regime and the 'turn to export-led industrialization' in 1965, Chibber ends up in an absurdity - attributing to a cause located in 1965 the capitalists' acceptance of the installation of a disciplinary regime in 1961.

12 Chang, 1993, p. 153.

13 Ibid.

${ }^{14}$ Amsden, 1989, esp. chs. 10-12 on nonlinear diversification, steel and shipbuilding. The distinction between ISI and ELI is rather artificial in the Korean context. But Chibber seems never to have compared import substitution after 1965 with export promotion. Was the former less efficient? Note Amsden again: 'Although exports were encouraged, steel was primarily an importsubstitution industry' (p. 316). It matched Japanese levels of efficiency. 


\section{Endorsing Capitalism}

How has Chibber come to be in such a tangle? And why does it matter so much? He comes to the Korean case with a set of assumptions drawn from institutionalist debates on 'Western' capitalism (whether in developing and developed countries). These accounts (whether on the welfare state or on import-substituting regimes in Latin America) typically pay little attention to class struggle, or to the links between exploitation, accumulation, and legitimation. And although the ghosts of 'neo-Marxist' debates from the 1970s hover over Chibber's account, they manifest themselves only in an attenuated form, in the argument that the state cannot act directly against capitalist interests. However, by reducing the latter to the interests of actually existing capitalists, Chibber falls into an instrumentalist trap; and he compounds the error, as we have seen, by imagining such an actually existing capitalist class in Korea, independent of the state in the sense that it has its own accumulation model already in place. One consequence of this is that he cannot grasp the logic of the capitalist developmental state in Korea.

A more serious consequence, in terms of the general implications of the study, is that both the general analytical framework and its application to India end up reproducing the neoliberal critique of state intervention. This is inherent in Chibber's general argument regarding the contrasted logics and political incentive structures of import-substituting and export-led industrialization, where the former is characterized by inefficiency, rentseeking and the 'attenuation of competitive pressures' [34], while the latter reflects not a commitment to free trade so much as the pursuit of competitiveness in the global capitalist economy:

Unlike the case of ISI, where investment plans of local firms were shaped by the easy opportunities of the domestic market, firms in ELI had to adapt to the rigors of international competition. And from this difference in economic challenges came the difference in political incentive structures [36].

I do not think we are in Korea any more. The general argument is dubious, as the state can as easily subsidise exports as import substitutes. In Korea, where import substitution fed directly into the export effort, rather than into 'easy opportunities' in the domestic market, it makes no sense at all. Behind Chibber's contrast between import-substituting and export-led 
industrialization respectively there lurks something else: an uncritical acceptance of the neoclassical view of competition as an unqualified good, and of the folly of seeking to buck the market. His account of Korea is completely distorted by this logic, and his account of India entirely shaped by it.

\section{Falling into the Arms of the World Bank (and the IMF)}

Chibber concedes at the very beginning of the study that 'the era of fullblown dirigisme may be over', suggesting at the same time that 'it is far from clear that some kind of state intervention at the sectoral or firm level is also a thing of the past' $[\mathrm{x}]$. His more general stand, which follows Johnson in every respect, is that the developmental state requires not just an efficient bureaucracy, but a nodal agency with the authority to coordinate policy [21]. In itself, of course, this is not a radical argument. One might charge a 'nodal agency' - say, for example, the Finance Ministry - with ensuring sound macroeconomic policy and coordinating microeconomic strategies to enforce a regime of competition across all policy areas, as the World Bank does today. And indeed, at the end of the book Chibber argues as follows:

In today's intellectual and political climate, in India and without, there is a sense that the era of state intervention in development is at an end. And certainly, as one witnesses the old scaffolding of the "licencepermit raj" being dismantled, it is possible to feel the momentum toward freer markets as something of an inexorable force. But to take this shift as the death knell of the state is to miss the essential lessons of Marx and Polanyi - the choice is over how to have the state intervene in the economy, not whether to have it intervene. Certainly, if the arguments developed here are any guide, the increasing emphasis the state is placing on exports is most likely to occasion a closer relationship between the state and exporting firms. More generally, there is good reason to expect that a liberalization of markets will lead not to less regulation but rather to a different regime of regulation - which can be more dense than the one preceding it. If this is the case, then the worries that animate this study - those of state capacity, internal cohesiveness, and its autonomy from social groups - remain of considerable interest. The turn away from a stateled development strategy will change the state's role, not erase it; whether the institutional capacities required for this new role in fact come about depends, as always, on politics [243].

Very well, but what kind of state does this suggest? The state dear to the World Bank, and specifically the Polanyi-inspired Wolfensohn-Stiglitz World Bank, with its own version of the East Asian developmental experience 
incorporated into its endorsement of the actively interventionist state promoting market-friendly development. ${ }^{15}$ Chibber is at one with the Bank's 2005 World Development Report, A Better Investment Climate for Everyone, which even addresses, albeit with caution, the circumstances in which selective state intervention might be appropriate. ${ }^{16}$ Not only that, but Raghuram Rajam, Economic Counsellor and Director of the IMF Research Department addressed the continuing 'closed' character of India in the following terms in New Delhi early in January 2005:

One explanation is the lack of confidence of our entrepreneurs. Till recently, our entrepreneurs, shielded by protection against domestic and foreign entry, felt they simply could not compete against foreign firms. Protection not only renders the beneficiaries lazy and inefficient, it also gives them less incentive to rectify distortions and inefficiencies in the system. Our corporations could not care less that finance was so costly during the License Permit Raj for the costs could be passed on to consumers. But when talk turned to liberalization, they argued they could not compete against foreigners who had access to much cheaper finance. And they are not unique in such complaints. An analysis of attitudes towards competition across the world shows that entrepreneurs are far more likely to oppose liberalization when their financial system is relatively underdeveloped. ${ }^{17}$

This is precisely where Chibber's analytical framework leads. He gives himself no stopping point short of an uncritical acceptance of competition as the lodestar of the developmental state.

15 See Cammack 2003, 2004. The reinvention of Marx as a patron saint of state intervention in this cause is an index of Chibber's theoretical affiliations.

${ }^{16}$ World Bank, 2004, Ch. 8. This is not all that surprising. Consider for example Johnson (1987, p. 140) on the logic of the capitalist development state: the elite's 'primary leadership task is to discover how, organizationally, to make its own developmental goals compatible with the market mechanism (that is, with such things as prices that are real measures of value, private property in theory and in practice, and decentralized decision-making)... [T] he truly successful ones understand that they need the market to maintain efficiency, motivate the people over the long term, and serve as a check on institutionalized corruption while they are battling against underdevelopment'; or even Amsden (1989, p. 18): 'The creation of competitiveness on the basis of an abundant, relatively well-educated labor supply is the key difference of latter-day twentieth-century learning'.

17 'India - A Hub for Globalization', at http://www.imf.org/external/np/speeches/2005/010705.htm, accessed 11 January 2005. 


\section{References}

Amsden, Alice H., 1989. Asia's Next Giant: South Korea and Late Industrialization, New York: OUP.

Cammack, Paul, 2003. 'The Governance of Global Capitalism', Historical Materialism, 11, 2: 37-59.

Cammack, Paul, 2004. 'What the World Bank Means by Poverty Reduction and Why it Matters', New Political Economy, 9, 2: 189-211.

Chang, Ha-Joon 1993. 'The Political Economy of Industrial Policy in Korea', Cambridge Journal of Economics, 17, 2: 131-157.

Chang, Ha-Joon 1998. 'Korea: The Misunderstood Crisis', World Development, 26, 8: 1555-1561.

Chang, Ha-Joon, Hong-Jae Park and Chul Gyue Yoo 2001. 'Interpreting the Korean Crisis: Financial Liberalization, Industrial Policy and Corporate Governance', in Financial Liberalization and the Asian Crisis, edited by Ha-Joon Chang, Gabriel Palma and D. Hugh Whittaker, London: Palgrave.

Chibber, Vivek 1999. 'Building a Developmental State: The Korean Case Reconsidered', Politics \& Society, 27, 3: 309-346.

Chibber, Vivek, 2003. Locked in Place: State-Building and Late Industrialization in India (Princeton and Oxford: Princeton University Press).

Chibber, Vivek 2004. 'Reviving the Developmental State? The Myth of the 'National Bourgeoisie', in The Empire Reloaded: Socialist Register 2005, edited by Leo Panitch and Colin Leys, London: Merlin Press.

Cumings, Bruce 1987. 'The Origins and Development of the Northeast Asian Political Economy: industrial sectors, product cycles, and political consequences', in The Political Economy of the New Asian Industrialism, edited by Frederic Deyo, Ithaca: Cornell University Press (first published in International Organization, 38, 1, 1984, 1-40).

Deyo, Frederic C. 1987. 'State and Labor: modes of political exclusion in East Asian development', in The Political Economy of the New Asian Industrialism, edited by Frederic Deyo, Ithaca: Cornell University Press. 
Haggard, Stephan, David Kang and Chung-In Moon 1997. 'Japanese

Colonialism and Korean Development: A Critique', World Development, 25, 6: 867-881.

Johnson, Chalmers, 1987. Political Institutions and Economic Performance:

The Government-Business Relationship in Japan, South Korea and Taiwan', in Frederic Deyo, ed, The Political Economy of the New Asian Industrialism, 136-164.

Kim, Eun Mee, 1997. Big Business, Strong State, Albany: SUNY Press.

Kohli, Atul, 1994. 'Where Do High Growth Political Economies Come From?

The Japanese Lineage of Korea's "Developmental State"', World Development, 22, 9: 1269-1293.

Kohli, Atul, 1997. 'Japanese Colonialism and Korean Development: A Reply', World Development, 25, 6: 883-888.

Pirie, Iain, 2005. 'The New Korean State', New Political Economy, 10, 2.

World Bank, 2004. World Development Report 2005: A Better Investment Climate for Everyone, Washington: World Bank/OUP. 


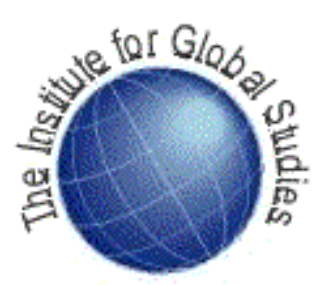

\section{Papers in the Politics of Global Competitiveness}

\section{Institute for Global Studies}

Manchester Metropolitan University

e-space Open Access Repository

http://www.e-space.mmu.ac.uk

1. The Politics of Global Competitiveness

Paul Cammack

Nov 2006

2. UN Imperialism: unleashing entrepreneurship in the

Paul Cammack

Dec 2006 developing world

3. Forget the Transnational State

Paul Cammack

Jan 2007

(C) Paul Cammack 2007. May not be used for commercial purposes. May be freely copied and distributed provided that the author and original and present publishers are given credit.

Cite as:

Paul Cammack, 'Class Pditics, Competitiveness and the Developmental State', Papers in the Politics of Global Competitiveness, No. 4, Institute for Global Studies, Manchester Metropolitan University, espace Open Access Repository, 2007.

This document was produced using Open Office Writer, an Open Source programme which is part of the Open Office Suite (http://www.openoffice.org) 